\title{
COMPONENTS OF PATH DEPENDENCE OF THE AGRICULTURAL PROPERTY MARKET IN POLAND
}

\author{
Magdalena Zaleczna, PhD, assist. prof. \\ Department of Investment and Real Estate \\ University of Lodz \\ e-mail:mzaleczna@uni.lodz.pl
}

\begin{abstract}
Agricultural real property has economic and social significance. An inseparable aspect of it is a historically and culturally shaped structure of ownership. The possibility of converting production of food into more profitable activity fans conflicts between the business-minded holders of farmland and the legislature seeking to protect the agricultural use of land, which have economic, but also social and political dimensions. Laws evolve in time and space, ranging from strict restrictions on transactions in land and few possibilities of changing its use to complete freedom of land use and disposal, with many intermediate solutions. This study is an outcome of author's interest in the broad context of changes occurring in this market. The article identifies the market's characteristics and its institutions, events, processes and mechanisms that provide insight into the present level of its institutional development.

In the author's opinion, tracing back the development of the Polish agricultural property market is useful for identifying opportunities that were missed and threats arising from 'path dependence'. The author studies the course of development of institutions, events and historic processes using desk research, analyses the findings of the available studies, and enhances the research process with creative thinking.
\end{abstract}

Key words: agricultural real properties, path dependence, Poland, restrictions.

JEL Classification: K11, K25, P26, Q15.

Citation: Zaleczna M., 2017, Components of Path Dependence of the Agricultural Property Market in Poland, Real Estate Management and Valuation, vol. 25, no. 4, pp. 05-12.

DOI: 10.1515/remav-2017-0025

\section{Introduction}

The real property market is special in a number of respects, for instance because of its heterogeneity, imperfection, limited effectiveness, low flexibility of demand and supply, and strong state interventionism (more in: KUCHARSKA-STASIAK 2016; SIEMIŃSKA 2011; BALL, LIZIERI, MACGREGOR 1998; EVANS 2008). These characteristics stem from the distinctive nature of a commodity such as property rights and the features of property itself, but chiefly from its immobility. One of the factors contributing to the heterogeneity of the real property market is the wide array of social and economic functions that properties can perform. Based on the criterion of function, the real property market can be divided into segments such as commercial properties, residential properties, agricultural properties, and their subgroups. There are, however, frequent problems with defining what criteria particular designates should fulfil.

The definition of agricultural real property is based on land's capability to produce and minimum acreage. This leads to interpretation problems, because a property can or cannot be viewed as agricultural depending on what laws are used to determine its status. The problem with establishing whether a real property is agricultural is not new and its main source is the fact that the commercial uses of land can yield higher income. Farmland owners are aware of it, so they tend to convert their 
holdings, particularly those located close to main routes or cities, to a more profitable use. The main factor behind land use changes is economic location that overrides high agricultural quality of soil. It is therefore the State's responsibility to decide whether the agricultural use of land should be protected and to what extent. The State's agricultural policy manifests itself through the degree of its intervention into the workings of the agricultural property market (MAŚNIAK 2011). Basically, there are two measures that the State deploys to control this market - it sets the rules of land use changes (which disturbs the mechanism of supply and demand for particular types of land), and exercises control over market participants (this also distorts supply and demand, because deciding who is eligible to buy agricultural property and controlling buyers' activities hinders access to the market and affects price levels).

In this article, the author focuses on this second aspect and investigates the institutional development of the agricultural property market in Poland. Special attention is given to the manifestations of a lock-in on ineffective solutions leading to the formation of path dependence.

\section{Path dependence - theoretical assumptions and a literature review}

The concept of path dependence was introduced into the economic literature in the 1980s with the works of P. David and B. Arthur (DAVID 1985; ARTHUR 1989; 1990), who studied development paths and location factors in the context of industrial projects from the historical perspective (DAVID 1985) and regarding increasing returns (ARTHUR 1989; 1990). Their special interest was in the circumstances causing the adoption and practical use of various technological solutions. What they found was that in contrast with the claims of the neoclassical theory a solution that has been put in use may not necessarily be the most effective one. This led them to the conclusion that the selection and persistent use of specific solutions is due to the occurrence of favourable circumstances. A broadly understood "history matters" concept proved so "handy" that it was soon absorbed by other social sciences, which directed attention to changes and evolutionary processes also in other areas (PUFFERT 2002; HISTORY MATTERS: ESSEYS ON ECONOMIC GROWTH 2004; BEBCHUK, ROE 1999; MAHONEY 2000; MARTIN, SUNLEY 2006). The essential feature of path dependence is the resistance to new solutions, a lock-in, and a 'noalternative' attitude that either prevents or hinders the introduction of new solutions, new products, or new institutions.

The canonical model identifies three key elements of path dependence:

1. A stochastic process in which some early event, mistake or opportunity exerts a far-reaching and long-term effect on economic and institutional development.

2. Following the event and after choice is made other options become unavailable, because specific circumstances favour the selected "path".

3. The lock-in goes on until it is broken by an exogenous shock.

For Arthur, increasing returns from specific solutions are a prerequisite for other options to occur. Increasing returns may come from high initial costs or fixed costs; learning effects (leading to the improvement of a product or reducing production costs), coordination activities which are undertaken when business organisations make similar decisions that enable their cooperation, adaptive expectations leading to a situation where the current scale of product distribution determines its future use (ARTHUR 1989).

David's concept is different in that he attributes the emergence of path dependence to economies of scale and to the positive effect of increasing market share on production costs. He also notes that because technological linkages are formed among users who operate some specific type of equipment using similar skills and share a mode of operation, a shift to a new system would involve the acquisition of new knowledge which entails a loss of time and costly errors (DAVID 2001).

A new perspective on 'path dependence' was presented by North, who sought to identify the sources of institutional changes and factors causing the emergence and entrenchment of differences between economies and societies, as well as contributing to the introduction, range and sustainability of changes (NORTH 1990, 1994). Following Arthur, North argued that increasing returns from the use of concrete solutions are necessary for 'path dependence' to take place, but he also added a number of other factors such as market imperfection, transaction costs and limited rationality in human decision making (NORTH 1994). His approach had a defining effect on later studies dealing with the role and manifestations of path dependence, because North abandoned earlier assumptions and set a new direction for research. Namely, he attributed causality to the process of institutionalisation rather than to some past event. Faced with the barriers of limited rationality and high transaction costs, an 
institutional change cannot take place unless high transaction costs are incurred. North was aware of the changeability of institutions and the continuity of changes, and found causality in entities pursuing their self-interest and competing organisations. The range of possible changes is determined by entities' past experiences and the present-day "mental models” are defined by the past. This model emphasises the historical continuity of institutions.

One the researchers who continued to use the path dependence theory for explaining phenomena and processes in social sciences was Pierson, according to whom increasing returns from some specific solution and 'a self-reinforcing process' are essential for path dependence to emerge (PIERSON 2000, 2004). Pierson argued that institutions derive their capacity to ensure increasing returns from established expectations arising from their earlier activities, and from their environment's interest in maintaining the status quo. Another important factor is that the costs necessary to transform institutions, acquired skills or coordination processes are usually high. Pierson noted that in the noneconomic sphere of social sciences a market pressure on changes is not observed. The political realm is distinctive in the presence of collective actions, a multitude of institutions and networks of relationships between them, asymmetric power relations and the intricacy of circumstances. Factors that have a special role in the stabilisation of path dependence are asymmetry of power and collective actions, which phenomena are not observed in the economy. Let us notice, however, that in the political realm entities have stronger influence on path dependence and change of government can be critical for the formation of new dependence path. It is especially notable that changes are not "frozen" but only reduced in scope, one reason for which is that some solutions created in the past are not useful any longer.

The emergence of a situation where only one option is available has three phases: the phase preceding the formation of path dependence, the formation phase and the lock-in phase (SYDOW, SCHREYOGG, KOCH 2009). The first phase comes with many options and actions the long-term impacts of which cannot be predicted. However, once choices have been made, an inclination arises to follow some specific line of action, which continues until some critical moment that terminates the current phase and paves the way for the second phase - the formation of path dependence. In this second phase, a new system (solution) starts to prevail, a self-reinforcing process emerges, the range of other options shrinks and the original choice becomes more and more resistant to change. Even so, other options are still available, a lock-in on one solution characterising the third phase that comes with inflexibility and impossibility of taking a different course has not happened yet. New entities that enter the system must abide by its rules. Although more efficient alternatives are available, both individuals and organisations follow the established decision-making pattern. The system closes itself to better solutions.

Development processes are continuous and are exposed to the influences of current events that always have roots in the past. The implication of this is that the pre-formation phase is not a 'tabula rasa case' because of the existence of some legacy. Although the legacy does not lead to a lock-in, it influences choices being made. Events that trigger the formation of path dependence do not have to be inconsiderable, but they must have unforeseeable consequences in the long term.

\section{Data and methods}

To the author's best knowledge, components of path dependence of the agricultural property market in Poland have not been investigated to date. The following procedure was adopted to investigate research problem: in the first stage a critical analysis of literature concerning the theoretical basis for creating the classic path dependence and a critical analysis of literature concerning the application of the theory of path dependence in a fields of economics, sociology and political science were conducted. In the second stage a critical analysis of the legal literature describing the regulations of property rights and use of agricultural land in Poland since the middle ages, critical analysis of the literature on social, economic and political relations in rural areas in Poland, including primary sources such as diaries, inventories, with particular reference to the nineteenth century and the first half of twentieth century were conducted. On the basis of the obtained knowledge the author selected processes and mechanisms that make up the beginning and the forming track of path dependence on the agricultural market in Poland. Finally, she summarized on the basis of the desk research and creative thinking. 


\section{Agricultural property market in Poland - current dilemmas}

The act on formation of agricultural system enacted on the eve of Poland's entry to the European Union imposed restrictions on the freedom of trade in agricultural property that had been introduced at the onset of transition in 1989. This legislative change was made to reconcile the EU's national treatment principle with Polish concerns over foreigners acquiring agricultural land. The act gave the Agricultural Property Agency a pre-emption right to agricultural property until the end of 2015, but it was only exercised in the case of 629 of 643,800 conditional contracts reported to the Agency (Raport z działalności ANR w 2015, p. 7). Effectively, a law that required two contracts (a contract of obligation and a contract of disposition) to be drawn up and consequently entailing administrative expenses had little effect on market transactions. Because the transitional period for the purchase by citizens from the EEA countries of agricultural property was scheduled to expire at the end of April 2016, an opportunity arose to tighten legal control over agricultural property transactions. The opportunity was seized and on 5 August 2015 the act on agricultural system development was passed. (Dz. U. item 1433). It was subsequently rescinded by the act of 14 April 2016 terminating the sale of properties in possession of the Agricultural Property Stock of the State Treasury and amending some acts (Dz. U. item 585). It also altered the 2003 act on agricultural system development that was made effective again. As in many other countries, these legislative changes aimed to "strengthen the protection and development of family farms" and "ensure the proper use of farmland" with a view to improving the area structure of farms and preventing excessive concentration or fragmentation of agricultural holdings (KRÓL 2013).

Liberal regulation of the agricultural property market in the years preceding the act on agricultural system development and the Agricultural Property Agency' reluctance to really exercise its preemption over market transactions in the period following the establishment of new institutional rules caused that restrictions on trade in properties entered as farmland into the register of land and buildings were toothless for many years. Because the prices of such properties were low and affordable, they were frequently targeted by investors who were also attracted by a wide choice of properties, unrestricted access and fast rising prices, particularly compared with prices quoted in other EU member states (ZAŁĘCZNA 2016).

The new law introduced in May 2016 is restrictive in that it limits the group of eligible buyers of agricultural property to entities ensuring its agricultural use. It will take some time before we know whether the changes produce the expected outcomes. Exempted from the act are properties smaller in area than $0.3 \mathrm{ha}$. The act defines an agricultural property as a holding that meets specific criteria and has an area of at least 1 ha. Agricultural properties that are designated in a valid zoning plan for nonagricultural purposes are not considered farmland. The fundamental question that needs to be asked here, particularly that local zoning plans cover a limited part of the country, is whether these exceptions are sufficient. The act prohibits the purchase for investment purposes of farmland - so loopholes have to be sought - that has been excluded from a zoning plan and that can be used commercially because of its economic location and low agricultural quality. While the act authorizes the competent public administrative body to release such properties for purchase by non-farmers, the procedure is complicated and the buyer must prove that they will reside on the property and will use it for agricultural production. If the Agricultural Property Agency fails again to effectively exercise its powers, transaction costs and distrust in law are likely to increase.

The amended act does not provide a comprehensive regulation of an issue as vital as agricultural leases. Many authors consider it important for the development of the Polish real property market and recommend that it be regulated (MARKS-BIELSKA 2010; MAJCHRZAK 2013, LICHOROWICZ 2010, ZIĘTARA 2009).

\section{Historical factors in the development of the Polish agricultural property market}

Law has for centuries been used to shape and control relations in the agricultural property market. Of the two spheres that were originally subjected to control - farm labour and possession of land - the first one was in time exempted from regulation. Poland's agricultural legislation is designed after the German model based on public law, so it is characterised by a high level of control (PRAWO ROLNE 2009). The agricultural property market developed as the number of players - potential buyers - was rising in the wake of social changes, particularly the abolition of serfdom. Eastern Europe dismantled its feudal system very late compared with countries in Western Europe. In Poland, efforts to better the 
living situation of peasants were made in a special situation - during the Kosciuszko Uprising in 1794. The Constitution of 3 May, 1791, extended general legal protection over peasants, but it failed to change their social status (ZIENTARA at el. 1988). The occupying countries (Prussia, Russia and Austria) had their distinctive agricultural legislation and aims, and the occupied territories differed in the structure of farms. The evolution of socio-political circumstances triggered by the defeat of the three powers in the war with Napoleon, popular movements during the Spring of Nations, as well as the January Uprising in 1863 led to the abolition of personal serfdom and thereafter to the emancipation of peasants. Different land-grant rules in the three partitions led to the emergence of different farm structures. The Prussian partition was characterised by larger farms and laws encouraging the enlargement of farms and prohibiting their division among heirs. In Austrian Galicia, the absence of restrictions resulted in substantial fragmentation of farms, widespread poverty and mass emigration (NONIEWICZ 2008).

In the inter-war period, attempts were made to reform the structure of land ownership. The act of 1920 was conceived as a means of easing palpable social tensions stoked by the situation of peasants. As its constitutionality was challenged (objections were raised by landowners), it was not until the enactment of the act on execution of land reform at the end of 1925 (Dz. U. of 1926, no. 1, item 1) introducing less stringent solutions that the land reform commenced. The land ownership structure was changing at a slow pace, though; voluntary division of land that was the reform's backbone was not popular with landowners. Moreover, the low level of industrialization in Poland contributed to the overpopulation of rural areas with people who had nowhere to go. Social and economic problems were additionally exacerbated by the Great Depression. The coincidence of all these factors led to further fragmentation of farms.

The socialist post-war years can be divided into three subperiods: 1944-1948 when land reforms were launched, 1948-1956 marked by collectivisation, and 1956-1989 known as the period of indirect socialisation (CZECHOWSKI at el.1999). The land reform was pushed through very quickly - its main legal vehicle was the PKWN's decree from November 1944. (Dz. U. no. 4, item 17). As far as the resettlement of the Regained Territories by repatriates, soldiers and inhabitants of central Poland is concerned, the key document was the decree from September 1946 on the agricultural system and settlement on the Regained Territories and the former Free City of Danzing (Gdansk) (Dz. U. no. 49, item 279). New farms were subjected to a maximum area limit of 15-20 ha for the Regained Territories and 5 ha for the other parts of the country. In 1948 collectivisation began, accompanied by measures intended to prevent trade in agricultural property and pressure on the formation of agricultural cooperatives. Another turning point took place in 1956 - legislation was amended and property transactions were allowed, but administrative control over farm area was not removed.

Following the return of democratic rule, the legislation on property transactions was amended. As before, the process can be divided into three subperiods: in 1989-2003 laws applying to trade and inheritance of farms were liberalized; in 2003, the act on agricultural system development imposing restrictions on land transactions was introduced to remain effective until 2016; in 2016, new, much more restrictive legislation on trade in agricultural property was introduced.

Table 1

Structure of farms by area in Poland, years 1921-2014

\begin{tabular}{cccccc}
\hline Distribution of farms by size groups (ha) & $\mathbf{1 9 2 1}$ & $\mathbf{1 9 3 8}$ & $\mathbf{1 9 5 0}$ & $\mathbf{2 0 0 0}$ & $\mathbf{2 0 1 4}$ \\
\hline $\mathbf{0 - 2}$ & 29.8 & 30.6 & $26.1(19.3)$ & 49.7 & 20.7 \\
\hline $\mathbf{2 - 5}$ & 32.9 & 33.8 & $34.5(17.4)$ & 21.5 & 32.4 \\
\hline $\mathbf{5 - 1 0}$ & 24.8 & 24.8 & $28.6(44,7)$ & 15.7 & 21.9 \\
\hline $\mathbf{1 0 - 2 0}$ & 10.4 & 9.5 & $9.5(17.5)$ & 9.4 & 15.4 \\
\hline $\mathbf{2 0 - 5 0}$ & 2.5 & 2.1 & $1.3(1.1)$ & 3.2 & 7.3 \\
\hline
\end{tabular}

* The numbers in the brackets relate to the Regained Territories

Source: developed by the author based on ZIĘTARA 2015, GUS statistical data.

The political, social, economic and legal changes have exerted influence on the structure of farms in Poland (tab. 1), but even though they were profound and dramatic the structure has not changed very 
much. It is still characterised by strong fragmentation of farms that has observable social and economic consequences.

\section{Phases in the formation of path dependence in the Polish agricultural property market}

As already mentioned, the literature divides the process leading to a lock-in on an ineffective solution into three phases. According to the author of this article, signs indicating that a problem exists include the emergence of persistently ineffective restrictions, disturbed functioning of the market mechanisms, the imposition of additional transaction costs and spreading belief that the legislative activity has nothing to do with business practice. No improvements are observed regarding the structure of agricultural holdings, productivity and farmers' living standard. The supply side of the property market is affected by restrictions imposed on small holdings that are only registered as farmland.

In analysing the development of the institutional agricultural property market in Poland and in trying to identify some triggering event in the past one has to bear in mind that even the hypothetical point, 0 " was not free of external influences. Politics substantially contributed to the formation of path dependence in Poland by allowing one social group to dominate and impose solutions that were convenient to it. It is unquestionable that the dismantling of the feudal system spurred the development of the institutional agricultural property market in Poland, even though the abolition of serfdom and the emancipation of peasants came as late as the 19th c. (in 1807, 1848 and 1864 in the Prussian, Austrian and Russian partitions, respectively). Not much time was left, therefore, for a cohesive farming class with its own culture, aspirations and principles to develop. As the land-grant laws in the three partitions were different, the structure of new farms and the economic status of the peasants were diversified too; larger farms on the Prussia-occupied territory enabled the education of future generations and modernization of farming. Even though both Prussians and Russians imposed restrictions on agricultural property transactions, in the Russian partition they were purely formal (NONIEWICZ 2008). Effectively, the Russian partition was similar to the Austrian partition where trade in real property was not restricted.

In the inter-war period, the Polish government made an attempt to introduce a land reform programme with a view to standardizing legal solutions across the country. Hypothetically, the reform can be taken as a critical point marking the onset of the path dependence formation phase. Its purpose was to improve the unfavourable structure of farms and the social position of peasants by making them legitimate market players. The plans to distribute land among peasants met with strong opposition from landowners, who were unwilling to accept and understand that social processes called for changes in ownership. At the same time, restrictions on trade in agricultural property were introduced to prevent the fragmentation of farms.

The revolutionary changes in the post-war period led to the abolishment of large landed estates, which were replaced by small individual holdings and extensive collective farms. Most individual farms were economically insignificant; their holders' small incomes were diminished by taxes and compulsory agricultural quota. Restrictions were imposed on agricultural property transactions, division and inheritance of farmland, some of which were commonly circumvented.

The transition years brought the liberalisation of legislation on trade and inheritance of agricultural properties, most of which were smallholdings rather than fully-fledged production enterprises. The process of ownership transformation was commenced - the responsibility for restructuring the stateowned land holdings was delegated to the State Treasury Agency for Agricultural Property (thereafter renamed the Agricultural Property Agency).

The legislation introduced in 2003 to restrict trade in agricultural property proved ineffective. The market basically acted as if no regulations were in force, only additional transaction costs had to be paid and disrespect for law developed. The fundamental question that we face today is whether we are facing another phase (lock-in) in the formation of path dependence. The new legislation of 2016 is another step in the same direction. Politics continues to be the decisive factor.

Many EU countries know and use instruments that allow the structure of farms to be improved. It must be remembered, though, that creating restrictions that remain unenforced disturbs market mechanisms, generates additional transaction costs and fuels disrespect for law and its makers.

\section{Conclusions}

This analysis of the development of the institutional agricultural property market in Poland has revealed opportunities that were missed as well as current risks arising from the existence of path 
dependence. Many agricultural properties in Poland, especially small holdings, are not strictly agricultural because the families that operate them need to seek additional sources of income. In the years before 2016 agricultural property was considered an attractive investment vehicle, promising return in the future when its status is converted to non-agricultural. The production value of farmland was viewed as secondary to the value of economic location, because commercially used land could yield higher income. The explanation for this can be sought in:

- the special structure of farms that has persisted for a long time,

- the non-existence of a distinct group of farmers-entrepreneurs,

- the lack of political will to make fundamental changes.

In the past, trade and inheritance of agricultural property were frequently subjected to various restrictions (such as transactions only between farmers, transactions having to be approved by the competent administrative body, or the heir having to prove farming qualifications), which were commonly circumvented. The economic, social and political aims of the legislature were not fully realised in practice.

As it seems, fundamental changes extending as far as thought patterns and other areas of legislation, especially that regulating land planning and use, are necessary to reform the agricultural property market. Comprehensive and consistently implemented, the changes should enable farmers to derive fair income from agriculture but also remove restrictions from many properties that are agricultural in name only.

\section{References:}

Agencja Nieruchomości Rolnych, 2016, Raport z działalności Agencji Nieruchomości Rolnych na Zasobie Wtasności Rolnej Skarbu Państwa w 2015 roku (Report on the activity of the Agricultural Property Agency on the Agricultural Property of the State Treasury in 2015).

ARTHUR B., 1989, Competing Technologies, Increasing Returns, and Lock-In by Historical Small Events, Economic Journal, no. 1, s. 116-131.

BALL M., LIZIERI C., MACGREGOR B. D., 1998, The economics of commercial property markets. Psychology Press.

CZeChOWSKi P., KorzYCKA-IWANOW M., Prutis S., StelmaChOWSKi A., 1999, Polskie prawo rolne na tle ustawodawstwa Unii Europejskiej (Polish agricultural law against the background of the legislation of the European Union), PWN, Warszawa,

DAvID P., 1985, Clio and the Economics of QWERTY, American Economic Review, vol. 75, no. 2, s. 332337.

DAVID P.A., 2001, Path dependence, its critics and the quest for ' historical economics', Evolution and Path Dependence in Economic Ideas: Past and Present, red. P. Garrouste, S. Ioannides, Edward Elgar, Cheltenham.

Evans, A. W., 2008, Economics, real estate and the supply of land, John Wiley \& Sons.

History Matters: Essays on Economic Growth, Technology and Demographic Change, 2004, W. Sundstrom, T. Guinnane (red.), W. Whatley, Stanford University Press, Stanford, s. 63-95.

JASIECKI K., 2013, Kapitalizm po polsku: między modernizacja a peryferiami Unii Europejskiej (Polish Capitalism: between modernization and the periphery of the European Union), Instytut Filozofii i Socjologii Polskiej Akademii Nauk.

KRÓL M., 2014, Przegląd wspótczesnych instrumentów wspierajacych zmiany struktury obszarowej gospodarstw rolnych $i$ wymiane pokoleniowa $w$ rolnictwie $w$ wybranych krajach europejskich (A review of contemporary instruments supporting changes in the structure of agricultural holdings and generation exchanges in agriculture in selected European countries), Fundacja Programów Pomocy dla Rolnictwa, Warszawa 2013.

KUCHARSKA-STASIAK E., 2016, Ekonomiczny wymiar nieruchomości (The economic dimension of the property), Wydawnictwo PWN, Warszawa.

LICHOROWICZ A., 2010, Potrzeba prawnego uregulowania dzierżawy rolnej w Polsce (na podstawie doświadczeń krajów Unii Europejskiej) (The need for legal regulation of agricultural leases in Poland (based on experience of European Union countries), repozytorium.amu.edu.pl.

MAHONEY J., 2000, Path dependence in historical sociology, Theory and society, 29(4), 507-548.

MAJCHRZAK A., 2013, Rola dzierżawy gruntów rolnych w kształtowaniu struktury agrarnej Polski na tle państw członkowskich Unii Europejskiej, Problemy Drobnych Gospodarstw Rolnych, 63. 
MARKS-BIELSKA R., 2010, Rynek ziemi rolniczej w Polsce: uwarunkowania i tendencje rozwoju (Market of agricultural land in Poland: conditions and trends of development), Wydawnictwo Uniwersytetu Warmińsko-Mazurskiego.

MARTIN R., SUNLEY P., 2006, Path dependence and regional economic evolution, Journal of economic geography, 6(4), 395-437.

MAŚNIAK J., 2011, Znaczenie polityki rolnej państwa w rozwoju rynku ziemi rolniczej w Polsce (Importance of agricultural policy of the state in the development of agricultural land market in Poland), Series G-Economy, Vol. 98, No. 3, 108.

NONIEWICZ C., 2008, Historia gospodarcza ziem polskich pod zaborami (Economic history of the Polish lands under the partitions), Wydawnictwo Uniwersytetu w Białymstoku, Białystok.

NORTH D. C., 1990, Institutions, institutional change and economic performance, Cambridge university press.

NORTH D. C., 1994, Economic performance through time, The American economic review, 84 (3), 359-368.

PIERSON P., 2000, Increasing returns, path dependence, and the study of politics, American political science review, 94(02), 251-267.

PIERSON P., 2004, Politics in time: History, institutions, and social analysis, Princeton University Press.

PrAWO ROLNe (Agricultural Law), 2008, Red. A. Stelmachowski, Wyd. Prawnicze LexisNexis, Warszawa.

Puffert D. J., 2002, Path Dependence in Spatial Networks: The Standardization of the Railway Track Gaug, Explorations in Economic History, s. 282-314.

SydOW J., SchreyOGG G., KOCH J., 2009, Organizational path dependence: Opening the black box, Academy of management review, 34(4), 689-709.

ZAŁĘCZNA M., 2016, Inwestowanie w nieruchomości rolne-Polska na tle wybranych państw europejskich (Investing in agricultural real estate - Poland against the background of selected European countries), Świat Nieruchomości, (96), 27-36.

Zientara H., MącZAK A., IHNATOWICZ I., LANDAU Z., 1988, Dzieje gospodarcze Polski do roku 1939 (The economic history of Poland until 1939), Wiedza Powszechna, Warszawa.

ZIĘTARA W., 2009, Model polskiego rolnictwa-wobec aktualnych wyzwań (A model of Polish agriculture to the current challenges), Zeszyty naukowe SGGW-Ekonomika i Organizacja Gospodarki Żywnościowej, 73.

ZIĘTARA W., 2015,. Społeczny czy ekonomiczny charakter reform rolnych w Polsce w okresie między- $i$ powojennym (The social or economic character of agricultural reforms in Poland during the postwar period), Roczniki Naukowe Ekonomii Rolnictwa i Rozwoju Obszarów Wiejskich, 102(1), 31-45. 